\title{
Curriculum Designs: Top-down or Bottom-up? -A Case Study in a Technological School of China
}

\author{
Hui $\mathrm{Li}$ \\ Faculty of Foreign Languages, Huaiyin Institute of Technology, Huai'an, China
}

\begin{abstract}
Competitive education around the world brings up many issues about curriculum design. In order to cultivate the ideal talents with abundant knowledge of language and specialties, it is necessary to design appropriate curricula. This comparative study has been carried out to discuss the appropriateness of curriculum designed for two parallel groups of English learners as a foreign language based on the survey in a technological school, a case study in China. In this special issue, curriculum design is likely to be problematic although it made a little improvement compared to the one before 2010: a) an analogical curriculum has been designed for both groups of students; b) what directions a curriculum design should follow, the more the better? c) how to balance a national curriculum, its localization and its implementation? d) top-down and bottom-up, language and specialty, which matters? This paper eventually puts forwards some suggestions which would be helpful for the future curriculum design.
\end{abstract}

Index Terms - curriculum, reform, English learners, ESP, top-down, bottom-up

\section{INTRODUCTION}

The boom of science and technology enables international exchanges and interactions more frequent and strengthened. China, as one of the members of WTO, has undoubtedly promoted her relationship with other countries, which provides a lot of opportunities in education along with challenges. Education could be examined as a "functional subsystem of economy wherein the economy is the dominant system"(Bank,2012). That is, economy is the drogue of education. The competition among different nations is highly dependent upon knowledge and intellectuals, hence the comprehensive and cross-disciplinary talents are demanded in order to meet the need of current situation. Cramer (2007)confirms that "basic, scientific, economic, and technological literacies, multicultural literacy and global awareness" should be included in the most common twenty-first century skills. Students are expected to acquire those twenty-first century skills to be competitive in occupational environment. English, as a lingual franca, plays an important role in global communication. Yet students are not just required to speak fluent English, however also solve problems in special fields so as to have the priority to their rivals in job hunting, future promotion and further study and something like that. In other words, students are not just learning to speak a foreign language, however to enact with it. They have to be trained with competence or "fitness" in the working environment to keep themselves maintaining, growing and flourishing(East,2000).

Government, educational departments, schools and universities are the crucial institutions to decide and conduct education reforms. Those institutions who are "responsible for preparing young people's professional, social and personal future" contributes to the impetus of different levels of curriculum reform(Oudeweetering \& Voogt, 2018). Therefore it is high time to revise the curriculum for school English education for the adaptation to the new era. Tyler'(2008) suggests that "educated people should take the initiatives to adjust to the society and improve it rather than passively accept the social order". Each individual is a subjectivity in the objective world. He added that it is school who has "the responsibilities to cultivate their pupils to fit into the current society and improve it accordingly". Schools stir young people to "understand well enough and participate competently enough in the present society to be able to get along in it and to work effectively in it while they are working to improve it" (Tyler, 2008). It is likely that both of these two implications should be included in a modern school. Priestley and Sinnema (2014)summarized three trends of curriculum development, among which the very first one is a shift from subject-based towards competence-based curricula. This aspect will be fully discussed in this essay. "An increasing focus on the centrality of the learner and an emphasis on active forms of pedagogy" comes into being the second trend. The third one can be reckoned as "an international movement towards standard-based and outcome-based curricula" (Priestley and Sinnema,2014; Sinnema \& Aitken, 2013).

Curricula are education activities which can be viewed as a form of internationalization, regionalization and localization(Wahlström, Alvunger \& Wermke,2018). To date many colleges and universities have improved their curriculum designs for non-English Majors and English Majors respectively so as to cultivate comprehensive graduates. The author takes his technological institute as a case of study. College English is an obligatory course for all the non-English major students. Meanwhile English is taught to English-majors in the Department of Foreign Studies. In 
the past decades, the curriculum requires the students to develop a strong skill of reading and a general skill of listening, speaking, writing and translating. However, as situation changes, it requires the students to develop a comprehensive skill of practice with English, especially listening and speaking, and use English orally and literarily in their future jobs. That is to say, students on one hand strengthen their general English ability, use English for their special purposes on the other hand. Non-English majors having their own specialties, once they can use English to solve some practical problems in their future jobs, they will be very competitive. On the contrary, English majors are seemingly in a dilemma not having practical skills like engineers because they only know the English language and its grammar. English after all is a tool of communication if they don't use it as the academic purpose or further study purpose. English majors are likely to have no advantages to compete with other majors. Chinese Ministry of Education issued English Teaching Syllabus for the every first time since 1980s, and then adapted for several times in the following three decades. The newest adaptation is the one in the year 2018. The national core curriculum for English language teaching is de facto a steer for nation-wide school language teaching at province-level. Because of the vast land and numerous schools, each school has conducted a slightly different curriculum policy at its own will. Many foreign language schools have changed their education policies after the national English Teaching Syllabus altered. The author has been at the service of a technological school for almost sixteen years. In his school, the department of foreign language studies designs the courses to cultivate the talents who master English and know economy and trade at the same time. Hence the English majors not only know the general languages, however also they can transfer to other fields like businessman, customs broker, and so forth. Accordingly, college English courses for non-English majors have been segmented into different sub-courses in order to make a switch from a general English to a more specific English. The target of making these changes in curriculum designs is to produce more competitive talents.

\section{THEORETICAL BASIS}

\section{A. The Influential Role of ESP}

ESP, as is well known, is short for "English for special purposes". Clearly it is the kind of English related to some special jobs or occupations. It is designed for the students with special learning purposes. Halliday and his co-author (1964) proposed in their book "The Linguistic Sciences and Language Teaching" the definition of ESP: "English for civil servants; for policemen; for officials of the law; for dispensers and nurses; for specialists in agriculture; for engineers and fitters". Generally speaking, general English teaching is not the only foci anymore. With the emergence of ESP, people from different language background can exchange their ideas and opinions in English in certain fields. People don't want interpreters to accompany them when going abroad for research or some international conferences. Now ESP has broadened its ranges from electronic trade, international finance, international trade to law, news, medicine, marketing, tourism, science and technology, academy, dissertation etc. It is time for educators to shift general English teaching to ESP teaching and change the curriculum of foreign language teaching. Richards(2008) gave us suggestion that we should "prepare materials to teach students who had already master general English, but needed English for use in employment, such as non-English background doctors, nurses, engineers, and scientists, prepare materials for people needing English for business purposes and future immigrants to deal with job situations". So learners' real needs should formulate the level of designing their English courses. Language needs may vary due to the different types of students restricted to their highly specific need.

\section{B. Bilingualism}

According to the Longman Dictionary of applied linguistics, Bilingual education meant "the use of a second or foreign language in school for the teaching of content subjects" (Richards, Schmidt, Kendrick \& Kim, 2005). Richards et al. categorized Bilingual education programs into different types as the followings:

a) The use of a single school language which is not the child's home language. This is sometimes called an immersion program;

b) The use of the child's home language when the child enters school however later a gradual change to the use of the school language for teaching some subjects and the home language for teaching others. This is sometimes called maintenance bilingual education;

c) The partial or total use of the child's home language when the child enters school and a later change to the use of the school language only. This is sometimes called transitional bilingual education.

Type b) maintenance bilingual education is normally the case in Chinese universities, especially involved with foreign language teaching. More importantly, many universities put forward the bilingual education program in order to introduce the up-dated information and knowledge to the students who are not English majors with original language versions. However the English edition materials are so difficult to understand that the teachers use home language and English to explain alternatively. It is likely to be beneficial to the students in order to get what the teachers say. In this way, students can improve their specific ability in English environment.

\section{A Comparative Study On CURriculum Design}


Although assimilation is a term in linguistics, the author tends to believe that assimilation can occur in the curriculum development to a certain extent. That is, the goal of the curriculum for "College English" and for "English majors education" assimilates towards the middle point. According to the investigation in author's technological school, the non-English majors are required to learn general English. In addition, they are also required to learn ESP so as to combine English to the specific fields. English majors, on the contrary, are trained to master all facets of general English, at the same time, to know about ESP in order to adapt to changing situation. Consequently the both of the graduates have similar ability - they have two swords: General English and English for Specific Purpose. After careful investigation the author summarizes the English curriculum in his technological school as the shown in Table I and Table II from 2003 to 2018.

\section{A. Current Curriculum Design of "College English”for Non-English Majors}

According to the 2004 Curriculum Require, college English should be divided into two parts: the EGP phase (freshmen and sophomore) and ESP Phase (juniors and seniors). The contents for freshmen and sophomores are mainly intensive reading for college English teaching: approximately 280 periods. Before 2010, college English curriculum performs the policy of 256 periods which are distributed into four academic terms (1st grade and 2nd grade) in author's school. The English courses segmented into two sub-courses: intensive course and listening course. The former one is taught in the classroom with only detailed explanation of texts and writing skills, while the latter is practiced in the language lab mainly with the students' automatic listening and some teachers' explanation. At that time "College English (revised)" chief-edited by Dong Yafen has been recommended as the textbook. No other English-related courses were offered to the students anymore. The purpose of learning English for the students was to pass CET4(College English Test -Band 4) and CET6(College English Test -Band 6), a famous national English proficiency test for college students held twice a year in China. From 2003 to 2010. College English teaching was performed in a rather simplified way, with 64 academic periods in total each term for four consecutive term at Year one and Year two. Intensive reading, writing, listening and speaking are the most important activities in classroom teaching. There's no clear cut between different teaching sessions. Only 16 periods have been allocated to the listening and speaking each term. After 2010, College English teaching reform was carried out one wave after another. In author's school 256 teaching periods were compressed into 192 periods. What is more, the number of college English course has been surprisingly increased, from four courses to twenty-three courses. In other words, students will spend less time in learning more English courses in classroom.

TABLE I.

COMPARISON OF COURSE DESIGN FOR NON-ENGLISH MAJORS

\begin{tabular}{|c|c|c|c|}
\hline Term & 2003-2010 & 2011-2018 & Times of opening \\
\hline \multirow[t]{3}{*}{ One } & \multirow[t]{3}{*}{ College English 1} & College English 1 & 7 \\
\hline & & College English(reading and writing)II & 7 \\
\hline & & College English(listening and speaking)II & 2 \\
\hline \multirow{7}{*}{ Two } & \multirow{7}{*}{ College English 2} & Oral English(preliminary) & 3 \\
\hline & & English listening & 3 \\
\hline & & English reading & 2 \\
\hline & & Practical English writing & 3 \\
\hline & & College English(reading and writing)III & 7 \\
\hline & & College English(listening and speaking)III & 2 \\
\hline & & College English III (video, listening and speaking) & 6 \\
\hline \multirow{8}{*}{ Three } & \multirow{8}{*}{ College English 3} & College English III（advanced English reading） & 2 \\
\hline & & College English Listening (intermediate) & 2 \\
\hline & & Chinese culture (English version) & 5 \\
\hline & & A guide to English-speaking countries & 5 \\
\hline & & Listening and notetaking skills & 3 \\
\hline & & College English IV & 7 \\
\hline & & Business English & 7 \\
\hline & & Intercultural communication & 7 \\
\hline \multirow[t]{6}{*}{ Four } & \multirow[t]{5}{*}{ College English 4} & $\begin{array}{l}\text { College English IV ( English for science and } \\
\text { technology) }\end{array}$ & 1 \\
\hline & & English literature & 2 \\
\hline & & Translation practice and appreciation & 3 \\
\hline & & Advanced English reading & 2 \\
\hline & & Western short stories & 1 \\
\hline & $\begin{array}{l}\text { Optional course(from } \\
\text { 2nd term to the } 8 \text { th } \\
\text { term) }\end{array}$ & $\begin{array}{l}\text { Tourism English } \\
\text { English writing } \\
\text { English movie appreciation } \\
\text { Japanese }\end{array}$ & \\
\hline
\end{tabular}


Table I and Table II illustrates the trend of college English curriculum development. From Table I we can see that more English-related courses were added to the choices for the students, most of which are ESP courses. Apart from some basic courses, students have the opportunities to choose some other ESP courses in the selective sector, for example, English literature, business English, and intercultural communication etc. College English curriculum not only alters in this institute. The same thing happened in other universities. In order to cultivate the law talents who are cross-disciplinary, practical, international, and globalized, the law school in Beijing Foreign Studies University provides the basic forensic courses taught by the foreign teachers, some of which are bilingual courses. In Tsinghua University, some optional courses are set to enhance the students' language skills who have different majors background, different language levels to improve the comprehensive ability. General education help those to promote the cultural quality while ESP courses provide the students language support in their specialties and help them to read professional articles effectively, strengthen their integrated ability of academic exchange as well as academic writing in the same round.

\section{B. Current Curriculum Design of Foreign Language Education for English Majors}

Under the guidance of foreign language education requirement, there are mainly five basic traditional core competence factors for English majors: excellent ability in listening, speaking, reading, and writing; good basis for literature; some knowledge for liberal arts; well-commanded of business English and proper ability in translation (Lai Zheng, 2009). However with the appearance of inter-disciplinary talents and instruction of "English teaching syllabus for English majors in higher education", Lai either mentioned that the above five competence should be upgraded to the following: public speaking and debate skills; academic writing; computer-assisted professional translation; promotion of Chinese cultures in English; some knowledge for English of science and technology. In other words, English majors should learn general English (GE) in the first two years and learn EST (English for Science and Technology) and EAP (English for Academic Purpose) or ESP (English for Specific purpose) in the last two years. The Department of Foreign Studies is a newly founded branch in author's school. The curriculum policy maker just imitate the curriculum approach from other universities as models to design courses for their own development. From Table II, we can see, seventeen courses are designed for English major students before 2010. All of the courses are the usual courses developed for English majors. Orientations to cultivate English majors in author's school are put much on the specific details of mastering English language and knowing business. General English education and business English are the two learning directions at that time. Yet the courses shown in Table II provide us more information than we apparently see. After the year of 2010, education reform helps refine the course curriculum and learning directions. English majors include general English, business English and translation. About 52 courses are designed for those English majors students, three times than those before 2010. The courses offered to different learning directions are much more obvious and sense-making. Literature, business, and interpreting are the three parallel directions to cultivate English majors to be specialized in some occupational fields.

TABLE II

COMPARISON OF COURSE DESIGN FOR ENGLISH MAJORS

\begin{tabular}{|c|c|c|}
\hline Before 2010 & After2010 & \\
\hline $\begin{array}{l}\text { Integrated English1-4 } \\
\text { Listening } \\
\text { Oral English } \\
\text { A general survey of the United Kingdom } \\
\text { and the United States } \\
\text { Literature of USA and UK } \\
\text { Advanced English1-4 } \\
\text { English phonetics } \\
\text { English Grammar } \\
\text { Linguistics } \\
\text { Lexicon } \\
\text { Bible culture } \\
\text { Intercultural communication in business } \\
\text { English for trade interpreters } \\
\text { E-trade English } \\
\text { French1-4 } \\
\text { Japanese1-4 }\end{array}$ & $\begin{array}{l}\text { An integrated English course I-III } \\
\text { Video listening and speaking I-III } \\
\text { Oral English } \\
\text { Society and culture of English-speaking } \\
\text { countries } \\
\text { An introduction to literature } \\
\text { Advanced English 1-4 } \\
\text { English phonetics } \\
\text { English grammar } \\
\text { An introduction to linguistics } \\
\text { English lexicology } \\
\text { English reading and writing I-III } \\
\text { Bible culture } \\
\text { Intercultural communication } \\
\text { Greek-roman mythology } \\
\text { Translation theory and practice } \\
\text { English public speaking and debating } \\
\text { English rhetoric } \\
\text { English practical writing } \\
\text { English drama } \\
\text { French 1-4 } \\
\text { Japanese1-4 } \\
\text { British and American literature (selected } \\
\text { reading) } \\
\text { British literature } \\
\text { English literature history } \\
\text { Selective reading of English novels } \\
\text { A history of English literature } \\
\end{array}$ & $\begin{array}{l}\text { Appreciation of English poems } \\
\text { British and American women's literature } \\
\text { Comparative literature } \\
\text { Intercultural business communication } \\
\text { Business English(integrated course)I-III } \\
\text { Reading for Business English } \\
\text { English for international business } \\
\text { negotiation } \\
\text { Business English writing } \\
\text { Cross-border E-commerce } \\
\text { International payment } \\
\text { International project management } \\
\text { Oral English in business } \\
\text { Computer-aided translation } \\
\text { Liaison interpreting } \\
\text { English-Chinese translation } \\
\text { Chinese culture } \\
\text { English-Chinese interpreting } \\
\text { Culture and translation } \\
\text { Translation criticism and appreciation } \\
\text { Chinese-English translation } \\
\text { A history of translation in china and the } \\
\text { west } \\
\text { Translation project management } \\
\text { Engineering translation } \\
\text { Culture translation } \\
\text { Simultaneous interpreting } \\
\text { Consecutive interpreting } \\
\end{array}$ \\
\hline
\end{tabular}


Comparing the two curriculum designs for English majors and non-English majors, it is notable that some similar revisions and directions appear. First of all, tremendous additions to the total number of the courses can be seen in either group of students. Over 5 times of the course added to the non-English majors and 3 times to the English majors. Both of them are focusing towards one direction: an inter-disciplinary talent, a moderate same point as illustrated in Figure I below. However each of them has its own advantage, we are likely to draw a conclusion that the non-English majors are trained to acquire the ability with "good command of specialties + English", by contrast, English majors with " good command of English + specialties". Culture, business, literature and translation are their common grounds. To be able to speak another language is not the ultimate purpose. Instead, to make good sense of a language and its culture and use it to do things becomes recognized in curriculum design and practice. Although they are approximately coming together toward the same point, they bear their own characters in curriculum feature. If we compare the curriculum design of Table I and Table II, non-English majors in the second phase are experiencing the first phase of curriculum practices of English majors but never follow up with it.

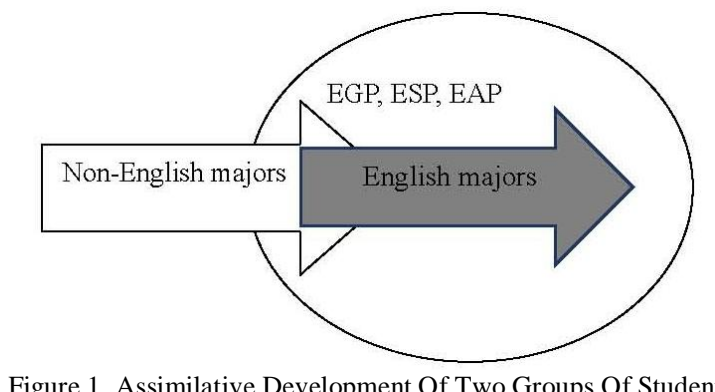

\section{Problems in the Curriculum Reform}

Every coin has two sides. Sense-making curriculum designs can do good to the English language teaching. Yet curriculum design without deliberation and need-oriented survey brings some fatal problems as well. Some extra requirements into the original plans for the four years of study means great effort should be made by teachers and students in learning and teaching. A sudden and large-scale change in curriculum design will affect the stability and sustainability of education.

\section{A. The Broken Linkage between Syllabus and Performance}

The design of syllabus and curriculum implementation is a weak link in the language research in China. First of all, curriculum design is more theory-based other than practice-based. Curriculum designer just borrow some theories in European countries or even more developed countries to formulate their own curriculum and syllabus. It's hard to localize the global one in certain schools. Second, a more nation-wide curriculum cannot meet the need of unbalanced English education in such an expanding area in China. Reaching shared understanding is not easy due to some social factors like interests, power relation, individual biases and frictions between resistance and change forces (Pyhältö, Pietarinen, \& Soini, 2018). To guide the language teaching, three parallel syllabuses: college English teaching, foreign language teaching, and preliminary English teaching are issued and revised occasionally. After the issue of national curriculum policy, it is somewhat difficult to realize it for different individual schools. Many obstacles are on the way including teaching staff and learning subjectivity. Teachers are the prominent component who realize the curriculum policy into a teaching action. Alvunger, Sundberg and Wahlström (2017) particularly emphasized that we need to understand the teacher's role as the one who transforms curriculum into practical teaching, with all the actual choices of inclusions and exclusions that such a transformation requires, and the one who converts the curriculum content into a form that becomes intelligibly and interesting for pupils.

Teaching is the form of realization of curriculum process in a combined context of teachers, students and classrooms. "The curriculum event in classroom settings jointly constructed by teachers and students" will not be accomplished without anyone of them(Alvunger, Sundberg \&Wahlström , 2017). In this special issue, the author found that in his institute, the problems like unaffluent qualified ESP teachers, no proper teaching materials, students' inactive involvement increase the difficulties to implement new curriculum effectively. Most of the teachers are reluctant to update their professional knowledge and teaching methods so that they couldn't adapt to the current situation. According to the survey to the English teachers, large proportion of the language teachers have no ESP learning experience and seldom refer to other subjects. How could an English teacher teach international trade interpretation well without knowing the trade itself at all? If we ask an international trade teacher to teach the course, he or she is also not qualified with English language proficiency. Therefore that's the biggest problem in implementing the reformed curriculum! Curriculum initiatives that do not include sufficient professional development for teachers are ulikely to have the positive effects intended(Timperley, Wilson,Barrar, \& Fung, 2007). What is more, students were offered so many choices for further learning each term, however they don't seem to have the interest in the ESP, EAP courses 
which are thought to be not useful in their future occupations. The curriculum solely based on the experience of one school may not be suitable or practical to the other. They lack of the concrete situation of language teaching in a concrete region.

\section{B. The Controversy Between English and Specialty}

Since English language is a compulsory course in China, students are learning English from primary and secondary school until universities, with consecutive learning for more than ten years. Learning English seems to be tedious and time-consuming. It really occupied plenty of time. In universities, students shoulder two responsibilities: to pass the CET and to master their own majors. How to balance the two things seems to be a problem to most students. According to a questionnaire on 4000 non-English majors in October 2004,carried out by China foreign language education centre, $19 \%$ of them spend almost all the time on English study, and 56\% of them spend most of their time on it ,and only $9 \%$ of them spend little. Many students increasingly complain about wasting so much of time in learning English that they couldn't have enough time to learn their professional majors. Consequently, some students cannot master their specialties with the result of failure in job hunting. English majors either encounter the same problem. They finally ignore the general knowledge and even at times they couldn't compete with non-English majors in language aspects, neither here nor there.

\section{Top-down or Bottom-up?}

Top-down and bottom-up are usually used to describe two different ways in implementing curriculum reform. Reforms that are grounded in research and theory can be defined as top-down wheras reforms that are heavily depending on teachers' involvement can be summerized as bottom-up (Mason, et al. 2005). Top-down approach bears the quality of power to change easily with less control of space and time. It looks like an arm-chair reseach which is more theoratical. On the contrary, bottom-up approach needs time and effort and has less power to be implemented. It is not uncommon that college English reform prefers the top-down to the bottom-up policy. Making a decision is an easy thing without any well-knit research before hand. Problems rise as we can see in Figure II below. Those course are ountlined merely by curriculum makers with their own empirism. No preparation work has been done before students are accessed to the new courses. From 2011to 2018, some course are regularly opened to students, intercultural communication, businiess English, college English(reading and writing)III, college English for instance. More specifically, some courses like western short stories, advanced English reading, English literature, collge English IV(English fro science and technology),college English listening(intermidiate),college English III(advanced English reading),English reading, college English (listenning and speaking)II, are opened no more than twice. That means students do not have the same courses to choose if they fail to pass the final examinations in the first round. Students push their way through loads of newly-opened courses which seems beneficial and fruitful.

This kind of curriculum design is more or less an action of casuality and arbitrariness. It is a waste of teaching resources and increases the burden of teachers and students. Li(2007) notes that any teaching reform has to be a sytemic combination of a "top-down" and "bottom-up" policy, considering all facets of teaching, learning and administrating in a rational distribution of responsibility, power and benefits. There's no single method to make a well-rounded curriculum. Top-down approach is not the only way in designing a curriculum. Curriculum mediators, teachers and students all should be involved. We should do the before-hand investigation and need analysis. Then we can know what students exactly like and what they need to develop themselves. Teachers either have the right to decide what is approriate to maintain within a sustainable and healthy curriculum. Students clearly know their own interest and their weakness and then improve themselves. It is not provable to open some of the courses if we don't do the need analysis on what kind of ESP courses students like or need to learn for their future. Need analysis and further investigation such as questionnaires, interviews should be the basic procedure before we make a curriculum reform. Both top-down and bottom-up should be employed.

Any teaching reform should be and must be based on need analysis to be sense-making and effect-making. The principle of a sound English language need analysis is to reckon students as an individuality and language user. From multi-facet angles, abundant analysis on certain student group have to be manipulated so as to obtain the relevant information of objective situation and learning context, contributing to the decrease of aimlessness and arbitrariness(Deng \& Chen, 2012). 


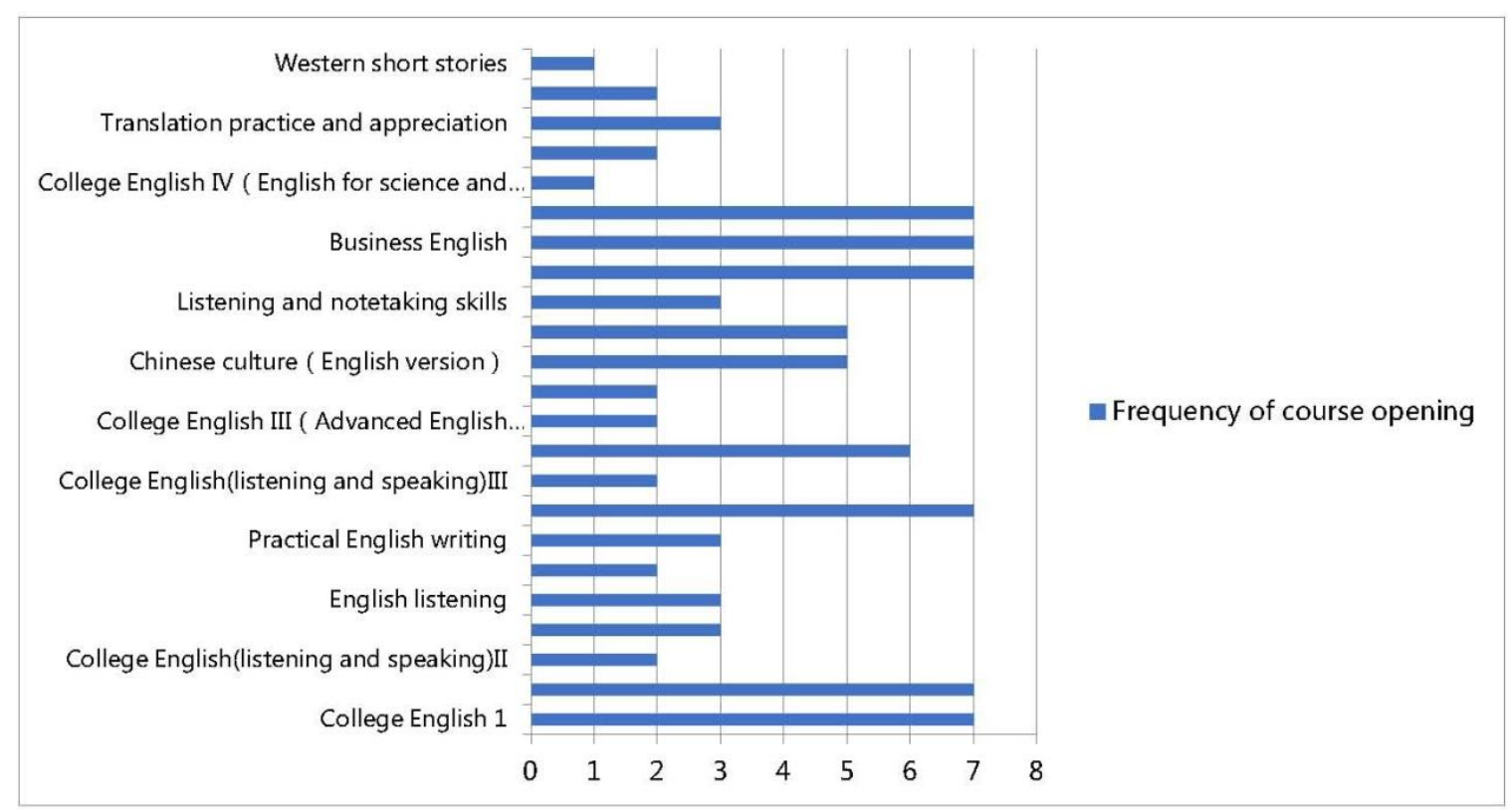

Figure 2. Frequency of Course Opening In A Technological School

\section{CONCLUSION}

The 21 st century is an era of science and technology, an era of information, an era of comprehensive intellectuals. The excellent talents should have both abundant knowledge of foreign languages and focusing specialties. It is really urgent to design good curriculum for the schools and teachers. More investigations and much analysis should be put forward to design suitable curriculums for the students. Each university has its own features to be considered. From this aspect, it is a must to think about what an ultimate university cultivating program is: to cultivate the talents to be fit for the local regions or global circumstances. It is very much necessary to consider the location in this special issue in author's technological school. Most of the graduates from this college are going to work in some big metropolitan cities like Suzhou, Wuxi, Shanghai, where located lots of joint companies. Combining a top-down and bottom-up approach, a sense-making curriculum, some kinds of ESP courses and the like, realistic goals should be of much concern. Only with these attempts and confirmation, can we make great progress at the furious competition.

\section{ACKNOWLEDGMENTS}

The authors wish to thank Professor Li Lisheng who gives many constructive suggestions.

\section{REFERENCES}

[1] Alvunger, D., D.Sundberg \& N.Wahlström. (2017). Teachers matters-however how? Journal of Curriculum Studies 49.1, 1-6.

[2] Bank, V. (2012). On OECD policies and the pitfalls in economy driven education: the case of Germany. Journal of Curriculum Studies 44.2, 193-210.

[3] Cramer, S. R. (2007). Update Your Classroom with Learning Objects and Twenty-First-Century Skills. The Clearing House: A Journal of Educational Strategies, Issues and Ideas 80.3, 126-132.

[4] Deng,Y. \& B. Chen(2012). Professional-stratification-based college English teaching on the basis of social needs analysis. Foreign Language Research 167.4, 123-126.

[5] East, K. (2000). Twenty-first century competence. The British Journal of Occupational Therapy 63.1, 1-1.

[6] Halliday, M.A.K., A. Mcintosh \& P. Strevens. (1964).The Linguistic sciences and language teaching. London: Longman.

[7] Li, X. (2007). A discussion on characteristics of college English teaching reform and its enlightenment. China University Teaching 3, 83-85.

[8] Mason, B., D. A. Mason, M. Mendez, G. Nelsen \& R. Orwig. (2005). Effects of Top-Down and Bottom-Up Elementary School Standards Reform in an Underperforming California District. Elementary School Journal 105.4, 353-376.

[9] Oudeweetering, K.V.D. \& J. Voogt. (2018). Teachers' conceptualization and enactment of twenty-first century competences: exploring dimensions for new curricula. The Curriculum Journal 29.1, 116-133.

[10] Priestley, M. \& C. Sinnema. (2014). Downgraded curriculum? An analysis of knowledge in new curricula in Scotland and New Zealand. Curriculum Journal 25.1, 50-75.

[11] Pyhältö, K., J. Pietarinen \& T. Soini. (2018). Dynamic and shared sense-making in large-scale curriculum reform in school districts. The Curriculum Journal 29.2, 181-200.

[12] Richards, J. C. (2008). Curriculum development in language teaching. Beijing: Foreign Language Teaching and Research Press. 
[13] Richards, J.C., R. Schmidt, H. Kendrick \& Y. Kim (eds.) (2005). Longman dictionary of language teaching and applied. Linguistics (2nd ed.). Beijing: Foreign Language and Research Press.

[14] Sinnema, C. \& G. Aitken. (2013). Emerging international trends in curriculum. In M. Priestley \& G. J. J. Biesta (Eds.), Reinventing the curriculum: New trends in curriculum policy and practice. London: Bloomsbury Academic.

[15] Timperley, H., A. Wilson, H. Barrar \& I. Fung. (2007). Teacher professional learning and development: Best evidence synthesis iteration. Wellington, NZ: Ministry of Education.

[16] Tyler, R.W. (ed.) (2008). Basic principles of curriculum and instruction; Translated by Zhang, Y. Beijing: China Light Industry Press.

[17] Wahlström, N., D. Alvunger \& W.Wermke. (2018). Living in an era of comparison: comparative research on policy, curriculum and. teaching. Journal of Curriculum Studies 50.5, 587-594.

[18] Zheng, L. (2009). Ten core competent factors for English-majors in Chinese universities. Foreign Language and Literature 25, 128-131.

Hui Li was born in Siping, China in 1978. He received his Master's degree in applied linguistics in Yunnan Normal University, China in 2012.

He now is a senior lecturer in the Faculty of Foreign Languages, Huaiyin Institute of Technology, Huai'an, Jiangsu China. His research interests cover corpus linguistics, second language acquisition and discourse analysis. 